\title{
Det diskursiva skrivandets funktion - en läromedelsanalys
}

\author{
Jenny Magnusson ${ }^{\star}$ \\ Södertörns högskola, Sverige
}

\section{Sammanfattning}

Flera forskare har visat att lärare i skolan inte undervisar tillräckligt mycket och tillräckligt tidigt i diskursivt skrivande, ett skrivande som elever behöver för att klara sig i samhället. Som en följd av detta har det diskursiva skrivandet under de senaste åren blivit allt mer uppmärksammat i nya styrdokument och i nya läromedel. Utgångspunkten i den här artikeln är att undersöka vilket stöd lärare får för att klara den uppmärksamheten, alltså de nya kraven som styrdokumenten ställer när det gäller diskursivt skrivande.

Det diskursiva skrivandets funktion undersöks här i skrivuppgifter i 19 läromedel i svenska för lågstadiet, där utgångspunkten är den stora betydelse som funktionen har när det gäller skolskrivande, i form av ett tydligt syfte, kontext och mottagare. Ivaničs skrivdiskurser är det analysverktyg som används, och skrivuppgifterna har kategoriserats utifrån dessa diskurser.

Det analysen visar är framförallt att variationen är liten i skrivuppgifterna. Eleverna får träna genreform och process, men inte mycket som har med funktion i en samhällskontext utanför skolan att göra. Därutöver visar resultaten att tydliga kontexter och tydliga mottagare är ovanligt i skrivuppgifterna, och i relation till tidigare forskning kan detta ses som problematiskt, då dessa aspekter har visat sig vara avgörande för ett framgångsrikt skrivande.

\section{Nyckelord: Diskursivt skrivande; skrivdiskurser; läroböcker; skrivuppgifter; svenskämnet}

\begin{abstract}
Several researchers have shown that teachers in schools do not teach discursive writing enough and early enough; a type of writing that students need to master to succeed in society. As a result, discursive writing has in recent years gotten more and more attention in new policy documents and educational materials. The premise of this article is to examine what support teachers receive to cope with this new attention.

Discursive writing is here examined in writing-assignments in 19 educational materials for primary school, on the Swedish language. The main focus is function, the important role that function has when it comes to school writing, e.g. in the form of a clear context or clearly defined recipients. Ivaničs discourses of writing is the analytical tool that has been used.

The analysis shows a little variation in the writing assignments examined. The students get to practice form of genre and process, but not much in relation with a social context outside of the schools. In addition, the results show that clear contexts or specified recipients are rare in the
\end{abstract}

${ }^{\star}$ Correspondence to: Jenny Magnusson, Södertörns högskola, Sverige.

Email: jenny.magnusson@sh.se

(C)2018 Jenny Magnusson. This is an Open Access article distributed under the terms of the Creative Commons Attribution 4.0 International License (http://creativecommons.org/licenses/by/4.0/), allowing third parties to copy and redistribute the material in any medium or format and to remix, transform, and build upon the material for any purpose, even commercially, provided the original work is properly cited and states its license. 
writing assignments, and in relation to previous research this can be seen as problematic, as these aspects have proven to be essential for successful writing.

Key words: Discursive writing; discourses of writing; writing assignments; educational materials; Swedish langauge

Received: August, 2017; Accepted: January, 2018; Published: March, 2018

\section{Det diskursiva skrivandets funktion - en läromedelsanalys}

Det diskursiva skrivandet, det utredande, argumenterande och redogörande skrivandet, har i en svensk kontext blivit alltmer betydelsefullt och lyfts fram både i forskning och i skolans styrdokument (Nyström Höög, 2010, Lgr11). Den tidigare progressionen där eleverna i lägre åldrar skrev berättande texter för att sedan mer och mer gå över till diskursiva dito har ändrats genom att eleverna nu förväntas skriva diskursiva texter redan i början av sin skolgång, i lågstadiet (jfr Nyström Höög, 2010; Hultman, 1989:136).

Forskning har samtidigt visat att det mesta som skrivs i skolan, både i Norden och $\mathrm{i}$ andra länder, är narrativt, berättande, och inte diskursivt ( $\mathrm{t}$ ex Brorsson Norberg, 2007; Herzberg, 2006; Nyström Höög, 2010; Berge, 2005 og Beard, 2000). Eleverna skriver texter som är skolspecifika, knutna till intimsfären och den personliga erfarenheten, och som inte är anpassade till den offentliga diskurs som finns utanför skolan (Berge, 2005). Just att skriva texter som är anpassade till och relevanta för en offentlig samhällsdiskurs som finns utanför skolan lyfts ofta i dessa sammanhang fram som särskilt centralt för skolans undervisning i svenska.

Mycket av nyare skrivforskning utgår också från en delvis ny föreställning om vad en text och vad skrivande är. I nyare skrivforskning ses skrivandet av en text som en medveten kommunikativ handling, och att det då alltså är vad skrivandet ska användas till, den kommunikativa funktionen, som är det centrala. Ongstad (2004) var med sin tredelade genremodell en av de skrivforskare som tidigt argumenterade för ett kommunikativt eller funktionellt perspektiv på skrivande. Han konstruerade en genremodell bestående av form, innehåll och användning, där användning motsvarar den funktionella dimensionen och är tänkt att bestå av syfte, mottagare och situation. Undersökningar ( $\mathrm{t}$ ex Smidt, 2010) har visat att elever behöver veta varför de skriver och till vem de skriver för att bli framgångsrika i sitt skrivande. Ivanič har också identifierat olika synsätt eller funktioner med skrivande genom det som hon kallar skrivdiskurser (Ivanič, 2004). Både diskursivt skrivande och skrivandets funktion har alltså i forskningen blivit framlyft och fått en ökad betydelse, och relationen dem emellan, det diskursiva skrivandets funktion, är också fokus för denna undersökning.

I linje med den nyare skrivforskningen har styrdokumenten för den svenska skolan förtydligats, där till exempel det diskursiva skrivandet i den senaste kursplanen i svenska för årskurs 1-3 (LGR11) skrivs fram tydligare än tidigare och också följs upp genom att bedömas i det nationella provet i årskurs 3. Nya direktiv i form av styrdokument ställer nya krav på lärare, dels i form av nya kunskaper och dels i form av 
nya pedagogiska material. Läroböcker är enligt undersökningar som har gjorts i skandinaviska kontexter fortfarande det som styr undervisningen i klassrummet (Otnes, 2015; Skolverket, 2006), och efter förändringar i styrdokumenten är det rimligt att tänka sig att läromedlen blir än mer relevanta för att stötta nya och mer erfarna lärare i sin förändrade praktik. Av den anledningen undersöks det diskursiva skrivandets funktion i just läromedel.

Denna undersökning tar sin utgångspunkt i de nya styrdokumentens formuleringar och kritiken som riktas mot den ensidiga inriktningen på narrativt skrivande. Syftet är därför att undersöka hur det diskursiva skrivandets funktion framkommer i skrivuppgifterna i ett antal läromedel i svenska för årskurs 1-3, där funktion förstås som explicit syfte, mottagare och situation.

- Vilka syften får det diskursiva skrivandet i läromedlen?

- Vilka mottagare har det diskursiva skrivandet i läromedlen?

- Vilka situationer rör det diskursiva skrivandet i läromedlen?

Diskursivt skrivande definieras på olika sätt i olika kontexter. Svensson (1995:9) definierar diskursivt skrivande som "strukturerade texter som successivt bygger upp och diskuterar en idé inom ett kunskapsfält och som bär sanningsanspråk" medan Brorsson Norberg (2007a:8) definierar diskursivt skrivande som "faktainriktade, reflekterande och argumenterande texter där förmågan att resonera är viktig". Jag väljer dock att utgå från Nyström Höögs definition av diskursiv text, där "skolans icke-berättande texter" inkluderas (2010:13), vilket i praktiken innebär ämnesrelaterade, faktabaserade, resonerande, beskrivande, argumenterande och utredande texter. Jag har kategoriserat alla skrivuppgifter som berättande/narrativa eller som diskursiva. De diskursiva skrivuppgifterna har jag sedan analyserat vidare.

\section{Tidigare forskning}

Utifrån syftet i denna artikel är det diskursivt skrivande, skrivuppgifter och skrivfunktion som är relevanta utgångspunkter. Det är framförallt norska och svenska studier som här tas upp och som varit särskilt relevanta i relation till metod och kontext för denna studie, framförallt när det gäller relationen till skrivuppgifter och läromedel.

Den kritik mot process-skrivande och fritt skrivande som kom från Hillocks (1986) omfattande forskningsöversikt i mitten av 80-talet och från genreskolan (t ex Martin 1984) banade väg för ett mer funktionellt skrivande där det diskursiva skrivandet lyftes fram särskilt. Birgitta Brorsson Norberg (2007), Catharina Nyström Höög (2010), Bergh Nestlog $(2009,2012)$ och Holmberg och Wirdenäs (2010) har alla skrivit om diskursivt skrivande i en svensk skolkontext, från mellanstadiet till gymnasiet. De fokuserar undervisning och skrivuppgifter på olika sätt. Brorsson Norberg (2007) undersöker skolskrivande och skolskrivandets kontexter, där elevtexter, undervisning och skrivuppgifter i högstadiet fokuseras. Hon visar i avhandlingen 
att många faktorer påverkar elevernas förhållningssätt till skrivande, där uppgifternas utformning och texttyp är sådana faktorer. Hon relaterar bristande undervisningssammanhang och enahanda traditionell undervisning till skolans organisation och bristen på kompetensutveckling och forum för ämnesutveckling. Bergh Nestlog (2012) undersöker diskursivt skrivande i årskurs 4-6, med fokus mot undervisningspraktiker och elevtexter, medan Nyström Höög (2010) undersöker skrivutveckling mellan årskurs 5 och 9, med fokus på textlängd, meningslängd och genre. Holmberg och Wirdenäs (2010) undersöker slutligen "icke-fiktivt skrivande" och skrivmodeller i olika högstadie- och gymnasieklassrum.

Det finns viss forskning som rör skolans skrivuppgifter, i relation till nationella prov och examinationsuppgifter (t ex Borgström, 2014) och, i mindre omfattning, i relation till läromedlens skrivuppgifter (jfr Otnes, 2015). Skrivuppgifter i årskurs 1-3 fokuseras dock sällan.

Relevanta studier där skrivuppgifter analyseras är Kvistad och Smemo (2015) och Veum (2015). I studien "Den gode skriveuppgaven? En studie av fellestrekk ved vellykkede skriveoppgaver fra Normprosjektet" (Kvistad \& Smemo, 2015) fokuseras skrivuppgiftsdesign särskilt, hur explicita och tydliga uppgifterna är. I Veums studie (2015) analyseras skrivuppgifter i olika läromedel i norska från olika tidsperioder. Utifrån Ivaničs teori (2004) runt skrivdiskurser analyserar hon vad i skrivuppgifterna som fokuseras vid olika tillfällen, och eftersom Ivaničs skrivdiskurser även valts i denna undersökning är denna artikel särskilt relevant när det gäller metod såväl som resultat. Hon kommer fram till att det finns skillnader i enhetlighet och utformning.

Otnes har genomfört flera studier om skrivuppgifter i högstadiet. Särskilt relevant är studien "Fiktive skriveroller og ukjente mottakere. Kontekstualisering i skriveoppgaver" (Otnes, 2013), där kontextuella upplysningar undersöks i 12 olika skrivuppgifter, huruvida det handlar om autentiska eller konstruerade skrivuppgifter och huruvida eleven får information om skrivsituation, skrivarroll (elev/roll), mottagare (känd/okänd/autentisk) och syfte i uppgifterna. För analysen av syfte används skrivhjulets funktioner. Hon ser att en mångfald av kombinationer finns. I studien "Skriv en tekst! Skriveoppgaver i lærebøker for norskfaget på ungdomstrinnet" (Othes \& Iversen, 2012) analyseras olika skrivuppgifter utifrån Ongstads genretriangel (innehåll, form, användning), och utifrån mottagare, syfte och situationskontext. De undersöker särskilt om funktion/bruk, som är ett nyare genrekriterium, ingår i läromedlens beskrivningar av skrivande. I båda dessa studier undersöks aspekter som ska undersökas även i denna artikel - syften med skrivuppgifter, skrivuppgifters mottagare etc, även om det är andra stadier och inte specifikt diskursivt skrivande som är i fokus.

En relevant undersökning när det gäller skrivuppgifter är också Westmans undersökning av läromedel i årskurs 4 (2012), där fokus är hur skrivuppgifter presenteras. Genom jämförelsen av ett äldre läromedel och ett nyare framkommer i undersökningen många likheter, till exempel att det i båda fallen handlar om 
isolerade färdighetsövningar och inte skrivande av hela texter med tydliga sammanhang. I resultatet diskuteras också betydelsen av mottagare, sammanhang och kontext, som inte alltid är synliga i uppgifterna.

Jag har också slutligen skrivit en ytterligare artikel utifrån samma ram och samma material som denna undersökning (Magnusson, inskickat manus), men där fokus istället ligger på hur det diskursiva skrivandet beskrivs i termer av skrivhandlingar och genrer, och vilka medierande redskap för att skriva diskursivt som förekommer i läromedlen. Det som framkommer är att det finns otydlighet i texttypologierna vilket tyder på att koncensus och vedertagna normsystem saknas, något som kan leda till otydlighet för såväl lärare som studenter. De medierande redskap som förekommer är relaterade till struktur, innehåll och språk. Medierande redskap relaterade till språk är dock mycket ovanliga, vilket kan ses som problematiskt men samtidigt rimligt utifrån vad som står i styrdokumenten.

Det finns sammantaget flera studier där skrivuppgifter undersöks utifrån olika perspektiv, framförallt i en norsk kontext. I flera studier undersöks också hur funktion eller syfte skrivs fram i skrivuppgifterna, och flera har också kommit fram till att syfte och mottagare är betydelsefullt i skrivuppgifter för att elever ska lyckas bra. I en svensk kontext finns dock färre studier, och studier från läromedel i årskurs 1-3 är också sällsynta, särskilt då med fokus på diskursivt skrivande.

\section{Teoretiska och metodologiska utgångspunkter}

Mitt övergripande teoretiska perspektiv i denna studie är det sociokulturella där utgångspunkten är att den sociala miljön är avgörande för lärandet, skolans övergripande verksamhetsmål (t ex Dysthe, 1996; Hoel, 2001). Språk, skrivande och texter ses alltså här som sociala fenomen. Utifrån ett sociokulturellt synsätt är undervisningsformer, kommunikation med lärare och pedagogiska material avgörande för elevernas lärande i det diskursiva skrivandets konst, och i denna studie är just dessa aspekter centrala. Detta synsätt är vedertaget inom såväl forskning som skolverksamhet.

\section{Funktion}

Skrivuppgifter speglar vad som är viktigt inom ett ämne - kunskaper, hållningar och färdigheter, något Skjelbred (2009) kallar en kunskapstaxonomi. Skrivuppgifternas funktion är det som ska analyseras i denna studie och Ivaničs skrivdiskurser har valts som analysverktyg för att komma åt denna funktion. Funktion och syfte används ofta synonymt, men jag har valt att använda funktion som ett mer övergripande begrepp än syfte i denna studie, för att skilja mina två analysnivåer åt där syftet ska förstås som en del av funktionen.

På en övergripande nivå kommer materialet att analyseras utifrån vilka skrivdiskurser skrivuppgifterna ger uttryck för. Utifrån Ivaničs perspektiv kan diskurser ses som analytiska ramverk som rör hur vi ser på skrivande, skrivutveckling, skrivundervisning 
och texters kvaliteter (Ivanič, 2004). Diskurserna rör olika dimensioner av skrivandet - texten, individens kognitiva processer, skrivhändelsen eller den sociokulturella/ politiska kontexten, och läromedlens formuleringar får betydelse för vad som betonas i skrivundervisningen och hur lärare och elever ser på på skrivundervisningens syfte eller funktion. I det här fallet är det synsättet som framkommer i skrivuppgifterna som analyseras, medan lärare i klassrummet naturligtvis kan ha ett helt annat synsätt vid användningen av skrivuppgifterna i klassrummet.

Ivanič har identifierat sex olika diskurser - färdighetsdiskursen, genrediskursen, processdiskursen, kreativitetsdiskursen, diskursen om sociala praktiker och den sociopolitiska diskursen. Veum (2015) har i sin analys av skrivuppgifter utifrån dessa skrivdiskurser valt bort process-diskurs och färdighetsdiskurs för att de inte varit lika relevanta. I denna analys kommer alla att tas upp, och sedan får analysen visa vilka som är mer eller mindre relevanta i relation till diskursiva skrivuppgifter.

Inom färdighetsdiskursen betonas själva texten och dess formsida. Språket ses där som ett verktyg och skrivutveckling handlar om att tillgodogöra sig regler och färdigheter. Inom kreativitetsdiskursen betonas elevernas kreativa förmåga, där intresse, engagemang och personliga erfarenheter är viktiga drivkrafter. Den personliga rösten är även viktig här. Inom processdiskursen fokuseras textens tillblivelseprocess där planering, revidering och omarbetning är centralt, liksom responsarbete. Inom genrediskursen fokuseras den sociala kontexten och hur skrivandet beror på denna, hur språket skiljer sig beroende på syfte och kontext. Diskursen om sociala praktiker fokuserar den sociala kontexten för textens tillblivelse där mottagare, kommunikativt syfte och kontexten utanför skolans ramar är central. Skrivandet görs här i autentiska sammanhang där det fyller en reell funktion. Den sociopolitiska diskursen påminner mycket om diskursen om sociala praktiker, förutom att det här också tillkommer en maktdimension, en identitetsdimension och ett kritiskt förhållningssätt till skrivande (Ivanič, 2004).

Förutom diskurser utgår jag också från hur syftet med en skrivuppgift kan förstås som en del av en genremodell eller genreteori. Form har sedan länge tillsammans med innehåll varit en utgångspunkt för skolans förståelse av genrer. Om det tidigare var innehåll och form som definierade genrer, har användning och syfte idag fått en lika stor betydelse som innehåll och form (Iversen \& Otnes, 2012), vilket t ex framgår av John Swales definition av genre: "genres are communicative vehicles for the achievement of goals" (Swales, 1990:46). Detta knyter till exempel an till Ledins (2001:26-29) definition av genre som prototypföreställningar om textutformning, syfte och mål, där en genre också ofta är namngiven och socialt kodifierad.

Inom olika språkvetenskapliga och didaktiska perspektiv är man idag överens om att syfte är viktigt för skolans skrivande, men det finns skillnader i hur syfte beskrivs och förstås. Många har försökt att identifiera skrivandets syften med hjälp av en annan mer grundläggande nivå än genrenivån, nämligen den nivån som beskrivs som textaktiviteter (Andersson Varga, 2014; Ledin, 2006) basgenrer (Holmberg, 2010) eller skrivhandlingar (Berge, Evensen \& Thygesen, 2016). Textaktiviteter, skrivhandlingar 
och basgenrer förstås här närmast som allmänna språkliga verksamheter eller processer, till exempel beskriva, berätta och utreda.

Inom den australiensiska genreskolan förstås skrivandets syften som någonting absolut och fast. Där finns olika grundläggande handlingsmönster, texttyper, som har givna syften. Texttyperna väljs utifrån de syften man har för sitt skrivande. Syftet med att beskriva är enligt genreskolan att "delge fakta" och detta görs i flera fasta steg (jfr Holmberg, 2010:17).

I den modell som tagits fram av norska skrivforskare, skrivhjulet, är syften med skrivandet den viktigaste utgångspunkten, men det är där inte frågan om fasta absoluta relationer mellan syften och handlingar. Där kan ett och samma syfte realiseras genom olika handlingar, skrivhandlingar, som skribenten vill uttrycka syftet med. Inom skrivhjulet identifieras sex olika grundläggande syften med skrivande som sedan kan realiseras genom olika skrivhandlingar. De sex olika syftena är 1) påverkan, 2) konstruktion av textvärldar, 3) kunskapsutveckling, 4) kunskapsorganisering och kunskapslagring, 5) identitetsskapande, självreflektion, metakommunikation och självbedömning och 6) utväxling av information, hålla kontakt (Berge \& Thygessen, 2014).

Ongstads genremodell (2004), inkluderar också ett kommunikativt eller funktionellt perspektiv på skrivande. Modellen består av form, innehåll och användning, där användning motsvarar den funktionella dimensionen och är tänkt att bestå av syfte, mottagare och situation. Jag har också valt att i denna studie förstå funktion som syfte, mottagare och situation, då den modellen tydligt kan relateras till Ivaničs diskurser och till det som framkommer i det empiriska materialet.

Det som jag har definierat som funktion - syfte, mottagare och kontext, är alltså det som jag kommer åt på en övergripande nivå genom analysen av diskurser. Diskurserna som sådana kan sägas motsvara syften med skrivandet, där det som fokuseras också är det som elever förväntas lära sig. Det jag tar fasta på i analyserna är vad som fokuseras och lyfts fram som centralt i skrivuppgifterna och det är detta jag relaterar till syfte. Diskursen om sociala praktiker och den sociopolitiska diskursen är därutöver relevanta i relation till analysen av mottagare och kontext.

För att komma åt syfte, mottagare och situation har jag valt att i första hand analysera skrivuppgifterna utifrån vilken skrivdiskurs de ger uttryck för, syften, och i andra hand att analysera skrivuppgifterna mer specifikt utifrån vilka mottagare och situationer som beskrivs för respektive skrivdiskurs. Mottagare och situationer tas upp i relation till respektive diskurs i de fall där det är relevant.

\section{Material}

Undersökningens material består av 19 läroböcker i svenska för årskurs 1-3. De läromedel jag har använt kommer huvudsakligen från de tre största läromedelsförlagen i Sverige; Gleerups, Liber och Natur \& Kultur och är läromedel som har sålts 
2016, det årtal då jag började med detta projekt. Urvalet är närmast slumpmässigt, och bygger på de läromedel som presenterats i försäljningskataloger under den tid då materialet insamlades. De läromedel som har använts är samtliga av förlagens så kallade basläromedel, böcker där allt som ingår i svenskämnet ska ingå, oftast uppdelat på årskurser. Jag har också använt läromedel som särskilt fokuserar specifikt på skrivande av texter. Jag har dock valt bort läromedel som enbart riktar in sig på skrivfärdighet, dvs stavning, ng-ljudet, hur man sätter punkt etc, vilket Westman (2012:204) beskriver i termer av övningar om skrivande till skillnad från övningar i skrivande. Flera av de 19 läroböckerna ingår i samma serie, men är uppdelade på olika årskurser. Inga lärarhandledningar är här slutligen inkluderade, även om det finns sådana i några fall. Detta beror på att det är en helt annan typ av stödmaterial och hade krävt en annan typ av analys.

Utifrån studiens övergripande sociokulturella synsätt har jag valt skrivuppgiften som analysobjekt (jfr Kvistad \& Smemo, 2015). Med skrivuppgift avser jag här de uppmaningar till och instruktioner för skrivande som finns i till exempel läromedel (jfr Skjelbred 2004). Vissa använder dock istället skriverbjudanden för att beteckna samma analysobjekt (t ex Westman, 2012).

Dessa skrivuppgifter är centrala för det lärande som möjliggörs för elever, och för det undervisningsstöd som erbjuds lärare. Jag har dock inte studerat hur skrivuppgifterna har använts i praktiken, vilket hade varit mest relevant i relation till ett sociokulturellt perspektiv. $\mathrm{Nu}$ får skrivuppgifterna snarast betraktas som potentialer för en praktisk skrivundervisning.

Det är enbart skrivuppgifter som avser fullständiga texter som här kommer att analyseras, och inte skrivande av isolerade färdighetsövningar. Med fullständiga texter avses här språkliga yttranden som knyts ihop genom kohesion och koherens och som har finalitet - början och slut (jfr Ledin, 1999). I analysen har jag alltså inte räknat in skrivuppgifter som enbart efterfrågar textfragment, $t$ ex "Skriv meningar. Skriv regler för Loves koja". (Hultén, 2009b). I vissa fall har kategoriseringen varit svår och det har varit svårt att avgöra om det är en text eller ett textfragment som det är tänkt att eleverna ska skriva. Jag har till exempel inte kategoriserat "Skriv om ditt favoritplagg" (Hultén, 2011a) som en diskursiv text då det inte framgår att det är en hel och avslutad text som avses, medan jag samtidigt har kategoriserat "Beskriv hur man gör när man vässar sin penna" (Hultén, 20011b) som en diskursiv text, då det $i$ anslutning till denna skrivuppgiftsinstruktion finns en fullständig modelltext som ska efterliknas.

Jag har utgått från texter som uttryckligen definierats som skrivande eller skrivträning utifrån kapitelrubriker etc. Det finns även skrivande under rubriker som läsande (skriv och berätta varför något hände i en bok som lästs) och samtalande (skriv en lista), men detta skrivande har alltså inte studerats här.

Innehållet i en skrivuppgift är av två slag, dels explicita instruktioner eller uppmaningar, dels de övningar, exempel, modelleringar och/eller dekonstruktioner av 
fenny Magnusson

Tabell 1. Materialöversikt.

\begin{tabular}{|c|c|c|c|}
\hline \multirow{2}{*}{$\frac{\text { Läromedel }}{\text { Prima svenska } 1}$} & \multirow{2}{*}{ Årskurs } & \multirow{2}{*}{$\begin{array}{l}\text { Räckvidd } \\
\text { Bas }\end{array}$} & \multirow{2}{*}{$\begin{aligned} \text { Antal d.uppg } \\
11\end{aligned}$} \\
\hline & & & \\
\hline Prima svenska 2 & 2 & Bas & 7 \\
\hline Skrivnivå 3 & $1-3$ & Skriv & 0 \\
\hline Boken om svenska. För 1:an & 1 & Bas & 1 \\
\hline Boken om svenska. För 2:an & 2 & Bas & 1 \\
\hline Boken om svenska. För 3:an & 3 & Bas & 6 \\
\hline Skrivmix. Start! läs och skriv i genrer & 3 & Skriv & 8 \\
\hline FORMA språket. Basbok ettan & 1 & Bas & 5 \\
\hline FORMA språket Basbok tvåan & 2 & Bas & 12 \\
\hline FORMA språket. Basbok trean & 3 & Bas & 11 \\
\hline Forma språket skriva A & $2-3$ & Skriv & 1 \\
\hline Forma språket skriva $B$ & $2-3$ & Skriv & 9 \\
\hline Bumerang skrivskola & 2 & Skriv & 10 \\
\hline Grönt ljus skriva åk 3 & 3 & Skriv & 6 \\
\hline $\begin{array}{l}\text { Språkskrinet: vi lär ordkunskap, språklära, } \\
\text { skrivning } 1 \text { (troll) }\end{array}$ & $1-3$ & Bas & 0 \\
\hline $\begin{array}{l}\text { Språkskrinet clown: vi lär ordkunskap, } \\
\text { språklära, skrivning } 2 \text { (clown) }\end{array}$ & $1-3$ & Bas & 2 \\
\hline Diamantjakten & Fk-3 & Bas & 5 \\
\hline Skriva svenska. Start & & Skriv & 5 \\
\hline Skriva svenska. A & & Skriv & 6 \\
\hline
\end{tabular}

diskursiva texter som fungerar som underlag för senare instruktioner. Modelleringar och dekonstruktioner kan $\mathrm{t}$ ex handla om att exempel på diskursiva texter presenteras och eventuellt också analyseras (dekonstrueras) utifrån typiska drag.

I tabell 1 finns en översikt, där titel, årskursangivelse (förskoleklass - årskurs 3) och räckvidd (basläromedel - skrivläromedel) anges för läromedlen, liksom antal diskursiva skrivuppgifter i respektive läromedel (antal d.uppg).

Materialet består av samtliga diskursiva skrivuppgifter som de 19 läromedlen innehåller. Jag har först samlat in de olika skrivuppgifterna och sedan kategoriserat dessa som diskursiva eller narrativa. För en sådan grundläggande kategorisering utgick jag från Nyströms definition av diskursiv text (2010) och mer specifikt från den grundhandling som skrivuppgiften består av (jfr Borgström, 2014). 106 skrivuppgifter kategoriserade jag som diskursiva, och dessa fördelar sig relativt jämt mellan de olika läromedlen, även om det också finns ett fåtal läromedel där det helt saknas diskursiva skrivuppgifter, och läromedel där det finns många.

\section{Resultat - Det diskursiva skrivandets funktion}

Skrivuppgifternas funktion anges aldrig explicit utan framkommer genom en analys av vad som betonas och fokuseras i skrivuppgifterna. Det som betonas och fokuseras 
Tabell 2. Översikt över skrivuppgifternas diskurser.

\begin{tabular}{ll}
\hline Diskurser & Antal skrivuppgifter \\
\hline Genrediskursen & 97 \\
Processdiskursen & 90 \\
Diskursen om sociala praktiker & 10 \\
Kreativitetsdiskursen & 3 \\
Färdighetsdiskursen & 0 \\
Den spociopolitiska diskursen & 0 \\
\hline
\end{tabular}

i skrivuppgifterna har sedan analyserats utifrån vilka skrivdiskurser som detta ger uttryck för.

Utifrån analysen av läromedlens diskursiva skrivuppgifter förekommer framförallt två av de diskurser som Ivanič (2004) identifierat - genrediskursen och processdiskursen. Syften i dessa uppgifter har alltså med utvecklandet av genrekompetens och utvecklandet av skrivprocesser att göra. I en och samma skrivuppgift kan dock fler diskurser relevantgöras och då har dessa kategoriserats dubbelt.

Nästan samtliga av de kategoriserade skrivuppgifterna utgår från en process där tankekartor ska formuleras, stödord ska förberedas, utkast ska skrivas etc. Det förekommer också exempel på responsarbete efter att eleverna skrivit sina texter. Allt detta kan knytas till en processdiskurs.

I detta exempel (figur 1) relevantgörs aktiviteter som planera, skriva utkast, förbättra och rätta, allt tydligt kopplat till en process-diskurs där individens kognitiva process står i centrum. Inom den skrivdidaktiska forskningen används ofta distinktionen "writing to learn" respektive "learning to write" för att beteckna olika mål med eller perspektiv på skrivundervisning (jfr Mayher 1983). Utifrån den distinktionen indikerar den stora fokuseringen på processdiskursen tydligt att läromedelsförfattarna i de 19 läromedel som ingår i denna studie i första hand prioriterar "learning to write", där hantverket att skriva är det centrala, medan "writing to learn" där det handlar om skrivandet som verktyg för att lära sig mer om ett ämne är ovanligt.

I de flesta läromedlen står olika typer av texter i centrum, och på ett generellt plan utgår de därför från det som Ivanič benämner som genrediskursen (2004). Ofta nämns genrekategorier i instruktionerna - artikel, insändare och faktatext. Det kan också handla om rubriker som Faktatext och Recept. Begreppet genre används dock sällan (jfr Magnusson, inskickat manus). Alla läroböcker fokuserar och definierar heller inte dessa typer av texter och alla formulerar heller inte skrivuppgifter som uttryckligen syftar till att eleverna ska kunna bli medvetna om och tillägna sig kunskap om dessa typer av texter, vilket alltså ytterligare hade stärkt genrediskursen.

Två av läromedlen utgår dock helt från genrer eller typer av texter och vad som kännetecknar dessa, och där struktureras och tematiseras hela boken utifrån dessa (Hydén , 2010; Sahlin, 2008). I följande innehållsförteckning (figur 2) framgår att 


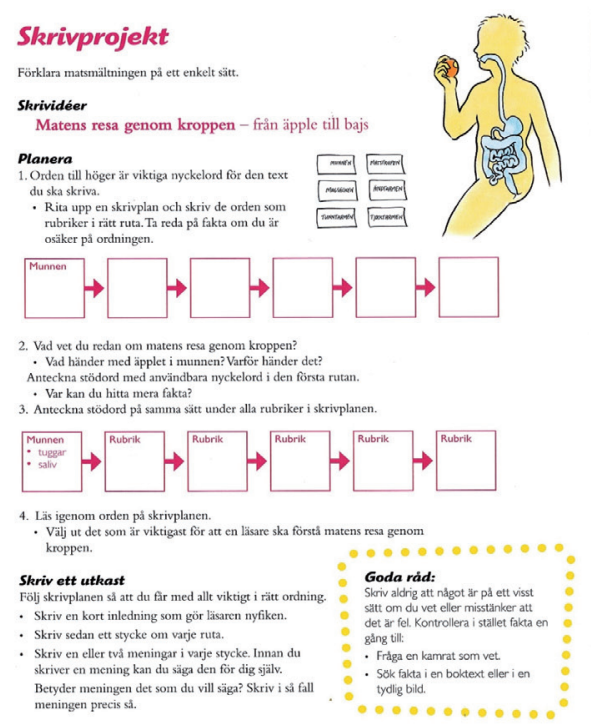

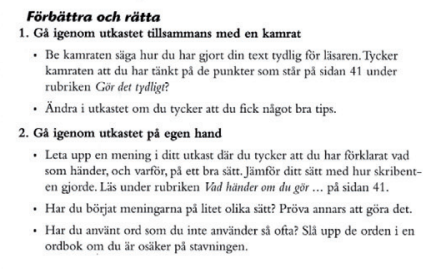

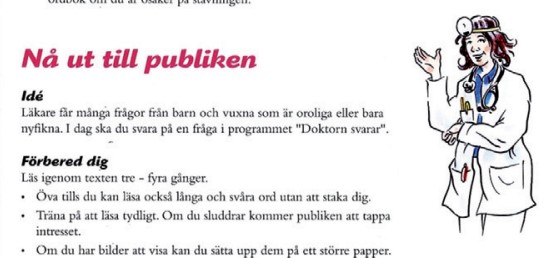

Om du har bilder att visa kan du săta upp dem pá ett större papper.

- Be en kamrat presentera dig och programmet for publiken.

Framträd

Först presentemer din her

Oorst presenterar din kamrat dig. Exempel: "I dag handlar

Sveriges främsta experter inom det ourardet, doktor ..."

Sedan kan du säga, till exempel: "Jag ska svara pă en mycket
nutressant fríga frăn en ... som undrar Vad händer med äpplet too

jagg at tujs?"”
Läs sedar fràn ditt papper, stycke for stycke.

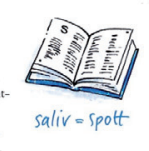

Tips!

sök att lasta som en expert - Làgg inte in nágot "Vad Laggg inte in naggot "Vad heter det nu igern"
ska du veta!

Figur 1. Process-diskurs (Hydén \& Martin, 2009:42-43).

läromedlen strukturerats utifrån typer av texter, vilket kanske inte är så anmärkningsvärt med tanke på att det läromedlet är fokuserat på just skrivande.

I exemplet (figur 2) förekommer t ex insändare och instruktion, genrer som kan kopplas till en genrediskurs genom att fokuseras och genom att genrerna får fungera som överordnade rubriker.

De andra läromedlen erbjuder också skrivande utifrån olika typer av texter, även om detta skrivande inte står i centrum och lyfts fram på samma sätt. I dessa läromedel finns många skrivuppgifter som går ut på att skriva texter där särskilda typiska sociala användningsmönster tränas och särskilda kännetecken synliggörs, vilket alltså då också kan knytas till en genrediskurs.

Innehållsförteckningen i figur 2 tyder allmänt på en stor variation när det gäller genrer. Än mer anmärkningsvärt är det då att de flesta skrivuppgifter ändå fokuserar på en process-diskurs, och då på en ganska likartad process med stegvist förfarande, planering genom tankekartor etc. Trots att rubrikerna alltså lyfter fram genrer är det inte skillnader i dessa genrer som självklart tas upp i de olika skrivuppgifterna utan en relativt likartad skrivprocess. Det finns alltså skrivuppgifter där det är tydligt att syftet är att skriva olika typer av texter med olika kännetecken, men ibland är det bara rubrikerna som indikerar detta syfte och inte själva skrivuppgiften eller skrivinstruktionen.

Eftersom diskursivt skrivande på ett allmänt plan framförallt ska förbereda för det skrivande som behövs i samhällslivet (jfr Berge, 2005) kunde man förvänta sig att diskursen runt sociala praktiker eller den sociopolitiska diskursen skulle vara relevant 


\section{Innehåll}

Välkommen! 3

1 Återberätta - en egen upplevelse 4

Fågelboet

2 Beskriva - fakta om ett djur 8 Jätteormen

3 Brev - personligt brev 12

Brev till Lina

4 Beskriva - en bokkaraktär 16

Bettan

5 Berättelse - en fabel 20

Schimpansen och kamelen

6 Instruktion - ett recept 24

Modellera

7 Berättelse - en folksaga 28

De tre bockarna Bruse

8 Bokrecension - säga sin åsikt 32

Den långa resan till Amerika

9 Dikt - en berättelse på rim 36

Vårpromenad

10 Förklara - vad händer och varför 40

Bakterier

11 Insändare - säga sin åsikt och övertala andra 44

Den perfekta presenten

12 Pjäsmanus - berättelse att spela upp på scen 48 Koka soppa på en spik

Figur 2. Innehållsförteckning (Hydén \& Martin, 2009). 


\section{$\star$ Beskriv en person}

\section{Ränaren}

Igår rånades Jamals butik. Du råkade vara i butiken samtidigt och var den ende som såg rånaren ordentligt.

Polisen ber dig att skriva ned en beskrivning av rånaren. På bilden här till höger ser du din egen minnesbild av det som hände.

Fyll i papperet från polisen på nästa sida.

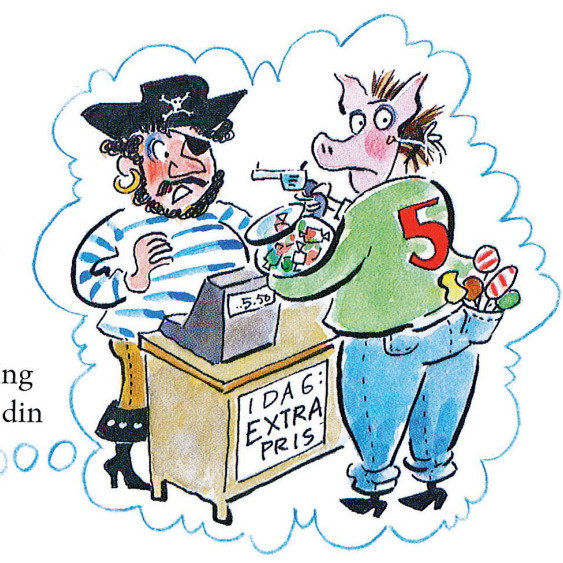

Figur 3. Skrivuppgift i kontext (Sahlin, 2008:27).

och synas i läromedlen. Detta är dock ovanligt. Vid tio tillfällen anges någon form av kontext till skrivuppgiften, ett sammanhang i vilket skrivuppgiften får en funktion. Det är dock enbart vid ett av dessa tillfällen en kontext utanför skolan och elevens privata sfär anges. Det är i dessa läromedel ovanligt att det offentliga samhället utanför skolan syns överhuvudtaget. Vid ett tillfälle görs försök att sätta in skrivuppgiften $i$ en offentlig samhällskontext, och då ska en beskrivande text skrivas för att fungera som ett vittnesmål.

I exemplet (figur 3) kontextualiseras en situation, en roll och en mottagare utanför skolans kontext - situation: rån $i$ en butik, roll för eleven: vittne och mottagare: polisen, som sedan fungerar som utgångspunkt för skrivuppgiften. Därmed får uppgiften ett tydligt syfte, att hjälpa polisen att få fast en brottsling. Allt detta kan knytas till diskursen om sociala praktiker och därmed till en kontext och en mottagare utanför skolans värld. Detta är dock det enda tydliga exemplet på diskursen om sociala praktiker, om villkoret är att både samhällelig kontext och mottagare ska finnas med. Den sociopolitiska diskursen förekommer överhuvudtaget inte i materialet.

Det finns dock exempel på läromedel där hela boken är en kontext, och där skrivuppgifter knyter an till denna. I exempelvis Forma språket (Hultén, 2009) får eleven följa barnen Mira, Ella och Love och sedan får eleven skriva texter utifrån denna kontext. Ett exempel är att det finns en skrivuppgift där eleven ska beskriva vägen till skolan för Ella, för att hon ska kunna hämta en fotboll som hon har glömt (Hultén, 2009:69). Även sådana exempel är dock få, och det är tveksamt om detta kan betraktas som exempel på diskursen om sociala praktiker, då det fortfarande rör skolans värld och då det är en privat och personlig vänskapskontext.

Många läromedel utgår i skrivuppgifterna från vardagsnära ämnen, sannolikt för att eleverna ska känna igen sig, men dessa texter verkar inte fylla någon tydlig reell 
funktion utöver att ämnena ska kännas välbekanta för eleverna. I ett av läromedlen uppmanas eleverna till exempel att skriva en instruktion till hur de tvättar håret eller borstar tänderna (Hultén, 2011a:74). Ett fåtal sådana exempel finns där skrivuppgiften sätts in i en personlig och vardaglig kontext. I ett exempel ges en situation, men ingen mottagare: "Du och några kompisar ska ordna en turnering i fotboll på skolan. Skriv ett e-postmeddelande med instruktioner om turneringen." (Bergman \& Jansson, 2011:31). Det är här oklart vem instruktionerna ska riktas till, även om man kan misstänka att det är andra elever på skolan.

Skrivuppgifterna sätts alltså sällan in i en kontext med ett tydligt explicit syfte eller en tydlig funktion. Det saknas också ofta mottagare till texterna vilket kan göra skrivuppgifterna mer svårgripbara för eleverna. De mottagare som ändå anges är, förutom polis som nämnts ovan, kompis, lärare, någon som aldrig har varit $i$ en simhall och utomjording.

- Skriv ett sms till en kompis (Hägg \& Perlkvist, 2014c:59)

- Skriv brev till lärare vad du har gjort i helgen (Hägg \& Perlkvist, 2014b:39)

- Skriv en instruktion till ngn som aldrig har varit i en simhall (Mårtensson \& Billström, 2010:50)

- Låtsas att du ska förklara för en utomjording hur det går till när vi människor borstar våra tänder (Felth Sjölund \& Hed Andersson, 2012:40)

Många av mottagarna som anges i skrivuppgifterna har alltså med elevernas vardagssfär att göra, medan mycket av innehållet istället handlar om djur, också vardagsnära, och bekant för många elever i den åldern. Eleverna skriver faktatexter om grisar, hästar, hundar, grisar, fåglar (av olika slag), katter, tigrar, igelkottar, kaniner, myror etc. Även instruktionerna rör vardagskontexten - vägbeskrivningar av olika slag, recept, spel, lekar, maträtter och aktiviteter som att tvätta håret, borsta tänderna, vässa pennan, häfta ihop papper etc.

De diskursiva skrivuppgifterna är sammanfattningsvis, trots sin tydliga status i styrdokument, nationellt prov och läromedel, inte så tydligt kopplade till det offentliga samhället utanför skolan, en av ambitionerna med ett ökat diskursivt skrivande i skolorna. Här kan argumenteras för att återgivande av fakta från en eller flera källor, som till exempel elevernas skrivande av djur-faktatexter ibland innebär, är en viktig kompetens vid rapportskrivande, utredningar etc., och därmed relevant $i$ en offentlig samhällskontext. För elevernas del hade dock en tydligare explicit kontext, inklusive mottagare och syfte, kunnat tydliggöra funktionen och meningsfullheten med detta skrivande och förmodligen också öka motivationen (jfr Ivanič, 2004; Smith \& Swain, 2011).

Hur det ser ut i klassrummet är dock fortfarande någonting helt annat än hur skrivuppgifter ser ut isolerat $\mathrm{i}$ en lärobok. Man kan här tänka sig att det är här lärarens didaktiska kompetens blir avgörande, att sätta in skrivuppgifter i ett relevant sammanhang och visa på vad skrivandet har för funktion. Samtidigt innebär detta att 
höga krav ställs på lärarna när det gäller att sätta in skrivuppgifter i en kontext och formulera funktioner med dessa.

Det som Ivanič benämner kreativitetsdiskursen (Ivanič, 2004) blir inte heller särskilt synligt i läromedlens diskursiva skrivande, vilket kanske är rimligt givet det diskursiva skrivandets roll i relation till det narrativa skrivandets, där det kreativa ofta får ett väldigt stort fokus i narrativt skrivande. Eleverna ges möjlighet att välja djur när de ska skriva faktatexter om djur, men utöver den typen av val är den diskursen osynlig i dessa sammanhang. Det finns dock en del förberedande arbete och idélistor som skulle kunna tolkas som kreativitetsuppmuntrande. Det finns också några enstaka exempel på fantasi-inslag i skrivuppgifterna, som skulle kunna fungera som intresseväckande och öppna upp för mer personligt styrda skrivuppgiftslösningar. Vid en skrivuppgift uppmanas eleverna vid ett tillfälle att låtsas kommunicera med en utomjording: "Låtsas att du ska förklara för en utomjording hur det går till när vi människor borstar våra tänder" (Felth Sjölund \& Hed Andersson, 2012:40). Vid ett annat tillfälle ska eleverna utifrån sin fantasi skriva en artikel: "Skriv klart artikeln om Herr Punkts olycka" respektive "Skriv tillsammans en artikel om när Fru Frågetecken hittade en gömd skatt i biblioteket" (Sahlin, 2008:29). En aspekt av kreativitetsdiskursen blir dock oftare relevant här, nämligen det som har med personliga erfarenheter att göra. Eleverna får ofta beskriva personliga intressen, erfarenheter och känslor (böcker, mat, erfarenheter av rädsla, glädje etc). Sammantaget är dock kreativitetsdiskursen inte tydligt relevant i relation till det diskursiva skrivandet, och hittas förmodligen oftare i det narrativa skrivandet.

Diskursen färdighetsträning är vanlig generellt i läroböckerna, men i relation till de diskursiva skrivuppgifterna där sammanhängande texter skrivs är detta perspektiv inte tydligt framskrivet, även om ett fåtal enskilda komponenter som övas vid skrivande av texter kan sägas vara färdighetstränande. Det skulle också kunna argumenteras att när flera olika skrivuppgifter uppmanar eleverna att skriva en och samma texttyp på samma sätt med samma fokus har det en färdighetstränande effekt, ett hantverk som ska tränas in genom övning och repetition. Utöver detta är det svårt att de hur specifika formella färdigheter tränas i relation till skrivuppgifterna, även om det vid enstaka tillfällen finns uppmaningar att inte glömma bort stor bokstav och punkt etc.

Om funktion analyseras utifrån diskurser är det sammanfattningsvis ganska tydligt att det är processdiskursen och genrediskursen som framförallt är relevant i relation till läromedlens diskursiva skrivande, där alltså funktionen med skrivuppgiften kan sägas ha med att lära sig processer och genrer att göra. Variationen är liten. Avsaknaden av diskursen runt sociala praktiker där skrivandet sätts in i en bredare samhällelig kontext är mer överraskande och kanske också mer problematisk med tanke på det diskursiva skrivandets roll att förbereda för det offentliga samhällets krav på skrivande. Överhuvudtaget får man bilden av att skrivandet i läromedlen handlar om att lära sig former och processer, men inte så mycket om att realisera 
kommunikativa behov, det som numera i Norge fokuseras i första hand genom skrivhjulet (jfr Bach, 2015).

\section{Avslutande diskussion}

En tydlig funktion med skrivande är något som ofta lyfts fram som centralt och avgörande för framgång, inte minst i relation till diskursivt skrivande som för många elever i skolans lägre årskurser är nytt och ligger långt från det skrivande som de använder hemma och är vana vid.

Funktion framgår inte explicit i de undersökta skrivuppgifterna, och jag har därför i den här artikeln använt Ivaničs skrivdiskurser för att komma åt funktion i läromedlens diskursiva skrivuppgifter. Det visar sig att det framförallt är genre- och processdiskursen som är relevant i relation till de diskursiva skrivuppgifterna i detta material, och att variationen är liten. I Veums analys (2015) togs process-diskursen bort, men här är den alltså högst relevant.

Tidigare forskning (jfr Berge, 2005) har kunnat konstatera att det i grundskolan ofta har handlat om narrativt och inte diskursivt skrivande. Fortfarande finns mycket narrativt skrivande också i dessa läromedel som är anpassade efter den nya läroplanen Lgr 11, men det finns nästan lika många exempel på diskursivt skrivande (jfr Magnusson 2017). Här har det alltså uppenbart hänt någonting och lärare och elever får här stöd $i$ att både narrativt och diskursivt skrivande är viktigt redan $i$ årkurs 1-3, åtminstone i läromedlen i svenska. I Veums analys (2015) verkar också funktionell sakprosa ha blivit vanligare, vilket tyder på att samma utveckling även finns utanför Sverige.

I årskurs 1-3 är inte skolämnena så tydligt åtskilda om man jämför med andra årskurser, vilket kan vara en anledning till att det framförallt är skrivande som learning to write som förekommer i läromedlens skrivuppgifter, medan writing to learn (jfr Mayher, 1983) lyser med sin frånvaro. I svenskämnets skrivuppgifter är det centrala alltså att skriva för skrivandets skull, mer än att lära sig olika ämnesinnehåll och använda skrivandet för ett sådant lärande. Skrivandet av faktatexter kunde ha varit exempel på writing to learn, men då eleverna till synes framförallt utgår från vardagskunskap som de redan har om framförallt olika djur, är detta inte heller det tydliga exempel på writing to learn.

Det hade säkert blivit andra typer av resultat om man hade undersökt andra ämnen, som längre upp i åren också blir mer tydligt avgränsade och fokuserade på ämnesinnehåll. Läromedel och skrivuppgifter inom andra ämnen än svenska, modersmålsämnet, saknar dock en tradition av att ha skrivuppgifter där eleverna ska skriva längre sammanhållna texter. Där är det mer kortare svar på frågor (jfr Kvistad, 2013). Dessa ämnen förändras sannolikt dock också utifrån nya direktiv i svenska styrdokument, där det betonas mer att alla lärare är språklärare och att språk- och skrivutvecklingen ska lyftas fram i alla ämnen (Lgr, 11). I annat fall finns en risk att elever enbart kommer i kontakt med skrivande för skrivandets skull när det gäller längre sammanhållna texter. 


\section{fenny Magnusson}

En annan aspekt som tagits upp som problematisk i relation till det narrativa skrivandets funktion är att det ofta i detta skrivande handlar om personliga erfarenheter och intimsfären, och inte förbereder för det skrivande som krävs för att delta och fungera i samhällslivet. Även Veum konstaterar att vardagsdomänen får ett större fokus på 2000-talet än vad det hade på 1970-talet, i relation till den sociopolitiska diskursen - politiska och samhällsrelevanta ämnen och ambitionen att förändra och påverka. Denna trend, som också denna undersökning visar på trots att det är diskursivt skrivande som studeras, går emot det som framkommit $\mathrm{i}$ forskning om hur viktigt just detta samhälleligt relevanta skrivande är (jfr Berge, 2005), men den går samtidigt i linje med den forskning som visar att det är viktigt att utgå från elevernas erfarenheter och intresseområden (jfr Gardner, 2008).

En viktig avsikt med att öka mängden diskursivt skrivande var just att eleverna skulle förberedas för det skrivande och de funktioner med skrivande som det offentliga samhället utanför skolan krävde, vilket ligger nära diskursen om sociala praktiker. Trots att närapå hälften av alla skrivuppgifter i läromedlen är diskursiva uteblir ändå denna relation till samhällsrelevans. Först och främst utgår både narrativa och diskursiva genrer framförallt från personliga intressen och intimsfären. Det diskursiva skrivandet handlar på samma sätt som det narrativa om elevernas vardag, kompisar och husdjur, spel och lekar. Detta kanske inte är så överraskande i lågstadiet, då eleverna här möter skolans skrivande för första gången och utifrån detta ter det sig inte helt orimligt att länka detta skrivande till erfarenheter från vardagslivet $\mathrm{i}$ första hand och samhällslivet utanför skolan i andra hand. Än mer anmärkningsvärt är det dock i ljuset av detta att skrivuppgifterna så sällan kontextualiserar och ramar in skrivandet - det framgår alltså sällan varför man skriver och i vilket sammanhang detta skrivande kan vara relevant och fungera oavsett om det handlar om en personlig eller samhällelig kontext.

Veum (2015) har dock kunnat konstatera i sin analys att det i hennes material har skett en ökning när det gäller skrivuppgifter knutna till diskursen om sociala praktiker. Det kan tyckas motsägelsefullt, men i hennes analys handlar det framförallt om att det nu är mer situationskontext i skrivuppgifterna, framförallt situationskontexter som har med vardagsdomänen att göra. Det är därför denna tendens av ökning står mot en tendens av minskning när det gäller den sociopolitiska diskursen i samma analys. Detta skiljer sig från vad som har framkommit i min analys, där såväl situationskontext som sociala praktiker är sällsynta i relation till skrivuppgifterna, vilket sannolikt framförallt beror på att hon har undersökt läromedel i högre stadier, där mönstren kan skilja sig åt.

$\mathrm{Nu}$ saknas elevperspektiv och praxis-perspektiv i denna artikel och det är omöjligt att med säkerhet veta hur dessa skrivuppgifter fungerar i praktiken. Om resultaten relateras till tidigare forskning som visar att eleverna behöver veta varför de skriver, till vem de skriver och vad texten ska användas till, för att skrivandet ska utvecklas och bli framgångsrikt (jfr Smidt, 2010) är det dock möjligt att anta att dessa skrivuppgifter skulle kunna bli mycket mer utvecklande. Det är möjligt att en lärare i en 
undervisningssituation ramar in uppgiften och lägger till det som i läromedlet saknas, men det ställer i så fall stora krav på en lärare och gör då också att läromedlet inte stödjer så mycket som det skulle kunna.

Ett liknande resultat som Smidt (2010) uppmärksammat, framkom också i Kvistad och Smemos artikel om skrivuppgifter (2015), nämligen att skrivuppgifterna som eleverna lyckats bäst med oftast hade tydligt definierade mottagare och sammanhang. Detta gäller även för Otnes (2013) även om fokus där framförallt låg på graden av explicithet i skrivuppgifterna. I ljuset av de resultat som framkommit i dessa undersökningar skulle skrivuppgifterna i dessa läromedel alltså kunna förtydligas i flera avseenden för att eleverna skulle kunna nå längre i sin skrivutveckling. Eleverna skulle behöva mer än stöd i att hantera isolerade former och processer. De skulle behöva explicita stöd och verktyg för att realisera kommunikativa behov.

Även Otnes och Iversen (2014) har intresserat sig för mottagare och situation i skrivuppgifter. De analyserade två läromedel utifrån Ongstads triangel och kom i sin analys fram till att alla delarna i triangeln - form, innehåll och funktion - användes i läromedlen ifråga, relativt balanserat och varierat. De undersöker dock inte enbart skrivuppgifter utan alla uppgifter överhuvudtaget. De undersöker också läroböcker för äldre stadier, där det kanske är mer vedertaget med funktionella skrivuppgifter. Det är ju enbart i de lägre åldrarna som detta med diskursivt skrivande är nytt, även om genresynen varit densamma för alla. Av den anledningen kanske inte skillnaderna mellan min studie och dessa studier förvånar.

Utifrån de skrivfunktioner som identifierats i skrivhjulet (Berge, 2005) är det slutligen framförallt funktionerna som har med kunskapsstrukturering som står i centrum i dessa läromedel och med viss tvekan även kunskapsutveckling. Flera av de andra funktionerna saknas, så även utifrån detta perspektiv blir läromedlens användning relativt begränsad - och eftersom funktioner och syften med skrivande nästintill aldrig explicitgörs kan skrivande och skrivuppgifter också uppfattas som både vaga och begränsade. Det ska dock också poängteras att kunskapsstrukturering och kunskapsutveckling är centrala och viktiga funktioner när det gäller diskursivt skrivande, även om inte detta perspektiv blir synligt i Ivaničs diskurser.

I Ongstads triangel (2004) fanns dock tre dimensioner som var viktiga med skrivandet - form, innehåll och funktion. Även om funktionen kan sägas vara vag eller närmast obefintlig i dessa läromedel är skrivuppgifterna mer utvecklade när det gäller innehåll och - framförallt - form. Dessa aspekter motsvarar ett traditionellt genrebegrepp, vilket tyder på att nya forskningsperspektiv kanske inte har sipprat ut helt och fullt i skolverksamheten eller läroboksförfattarverksamheten ännu. Det kanske inte är så underligt då det handlar om långsamma processer, men det är ändå viktigt att komma ihåg att både form och innehåll är viktiga aspekter när det gäller skrivande, som betonas också i skolans styrdokument. Det är också viktigt att komma ihåg att läromedel enbart är ett av flera verktyg som lärare har att tillgå. Skolverkets stödmaterial och lärarutbildningarnas undervisning spelar till exempel här i Sverige också stor roll i dessa sammanhang och skulle kunna undersökas vidare. 


\section{fenny Magnusson}

\section{Referenser}

Bach, C. (2015). Eksamensoppgaver i norsk etter 13 år. Sensorstemmer fra våren 2012 og våren 2014, I H. Otnes (red.) Å invitere elever til skriving: ulike perspektiver på skriveoppgaver. Bergen: Fagbokforlaget.

Beard, R. (2000). Developing Writing. 3-13. London: Hodder \& Stoughton.

Berge, K-L. (2005). Skriving som grunnleggende ferdighet og som nasjonal prøve - Ideologi og strategier. Det nye norskfaget, Fagbokforlaget: Oslo.

Berge, K-L. \& Thygesen, R. (2014). Skrivande som grundläggande färdighet: förståelse, bedömning och undervisning. I G. Skar \& M. Tengberg (red.) Bedömning $i$ svenskämnet. 63-86. Stockholm: Natur \& Kultur.

Bergh Nestlog, E. (2009). Perspektiv i elevtexter. Skriftligt argumenterande i grundskolans mellanår, Växjö: Växjö universitet.

Bergh Nestlog, E. (2012). Var är meningen?: elevtexter och undervisningspraktiker. Diss. Växjö: Linnéuniversitetet.

Borgström, E. (2014). Skrivbedömning: uppgifter, texter och bedömningsanvisningar i svenskämnets nationella prov. Diss. (sammanfattning) Örebro: Örebro universitet.

Brorsson Norberg, B. (2007a). Man liksom bara skriver. Skrivande och skrivkontexter $i$ grundskolans år 7 och 8 , Örebro: Örebro universitet.

Brorsson, Norberg, B. (2007b). Diskursivt skrivande i grundskolan, Svenskläraren, 51:4.

Dysthe, O. (1996). Det flerstämmiga klassrummet: Att skriva och samtala för att lära. Lund: Studentlitteratur.

Gardner, T. (2008). Designing Writing Assignments. National Council of Teachers.

Hagberg-Persson, B. \& Wiberg, C. (2013). Elever visar vad de kan: Två studier kring ämnesprovet $i$ svenska och svenska som andraspråk för årskurs 3. Report. Uppsala: Trycksaksbolaget.

Herzberg, F. (2006). Genreskrivning under senare skolar: att berätta räcker inte. I L. Bjar (red.), Det hänger på språket (s. 295-317). Lund: Studentlitteratur.

Hoel Lokensgard, T. (2001). Skriva och samtala. Lärande genom responsgrupper. Lund: Studentlitteratur.

Hultman, T. (1989). Skrivutveckling i ett pragmatiskt perspektiv, I C. Sandquist \& U. Teleman (red.) Språkutveckling under skoltiden. Lund: Studentlitteratur.

Ivanič, R. (2004). Discourses of Writing and Learning to Write. Language and Education. (Vol 18, 3) Lancaster: Lancaster University: Departement of Linguistics and Modern English.

Iversen H. M. \& Otnes H. (2012). Sjangrer og skrivehandlinger i lærebøker for norskfaget på ungdomstrinnet. I: FoU i Praksis 2011. Rapport fra konferanse om praksisrettet FoU i lcererutdanning. Trondheim: Tapir Akademisk Forlag.

Kvistad, A. (2013). Skrivekulturer i fagene norsk or RLE. En studie av tre lcereres oppgavepraksis på ungdomstrinnet. Masteruppsats, Høgskolen i Sør-Trøndelag: ALT.

Kvistad A. \& Smemo, J. (2015). Den gode skriveuppgaven? En studie av fellestrekk ved vellykkede skriveoppgaver fra Normprosjektet. I: H. Otnes (red.) Å invitere elever til skriving: ulike perspektiver på skriveoppgaver. Bergen: Fagbokforlaget.

Ledin, P. (1999). Texter och textslag: en teoretisk diskussion. Svensk sakprosa 27: Lund.

Läroplan för grundskolan, förskoleklassen och fritidshemmet 2011. (2011). Stockholm: Skolverket. Tillgänglig på Internet: http://www.skolverket.se/publikationer?id=2575

Magnusson, J. (2017). Läroboken och det diskursiva skrivandet: genrer, textaktiviteter och medierande redskap i läroböcker för årskurs 1-3. Manus inskickat för publicering.

Martin, J.R. (1984). Language, register and genre. I: Language, register and genre. Children writing: reader, I J. S. Mayher, G. M. Pradl \& N. B. Lester (1983). Learning to write/writing to learn. Portsmouth, NH: Boynton/ Cook Publ.

Nyström Höög, C. (2010). Mot ökad diskursivitet? Skrivutveckling speglad i provtexter från årskurs 5 och årskurs 9, FUMS-rapport nr 228, Uppsala: Uppsala Universitet.

Ongstad, S. (2004). Språk, kommunikasjon og didaktikk: norsk som flerfaglig og fagdidaktisk resurs. Bergen: Fagbokforlaget.

Otnes, H. (Red.) (2015). Å invitere elever til skriving: ulike perspektiver på skriveoppgaver. Bergen: Fagbokforlaget.

Otnes, H. (2013) Fiktive skriveroller og ukjente mottakere. Kontekstualisering i skriveoppgaver. I: Lereboka: studier av ulike lareboktekster. Trondheim: Tapir Akademik forlag.

Otnes, H. \& H. M. Iversen (2012) Skriv en tekst! Skriveoppgaver i lærebøker for norskfaget på ungdomstrinnet, Norsklcereren. vol. 2 (2).

Skjelbred, D. (2004). Skriving i læremidler i småskoletrinnet I S. Selander \& D. Skejbred (red.) Pedagogiske tekster for kommunikasjon og laring. Oslo: Universitetsforlaget. 


\section{Det diskursiva skrivandets funktion - en läromedelsanalys}

Skjelbred, D. (2009). Lesing og oppgaver i lærebøker. I Knudsen, K., Skjelbred, D. \& Aamotsbakken, B. (red.): Lys på lesing. Lesing av fagtekster $i$ skolen, s. 271-289. Oslo: Novus.

Skolverket (2006). Läromedlens roll i undervisningen. Rapport 284, Stockholm: Skolverket.

Smidt, J. (red.) (2010). Skriving $i$ alle fag - innsyn og utspill. Trondheim: Tapir Akademisk Forlag.

Svensson, J. (1995). Den diskursiva texten. I Holmberg, C.-G. \& Svensson, J. Medietexter och medietolkningar, Nora: Nya doxa.

Swales, J. (1990). Genre analysis: English in academic and research settings. Cambridge: Cambridge University Press.

Veum, A. (2015). Skriveoppgåver i utvikling? Skrivediskursar i norskbøker for ungdomsskulen gjennom 30 år, I H. Otnes (red.) Å invitere elever til skriving: ulike perspektiver på skriveoppgaver. Bergen: Fagbokforlaget.

Westman, M. (2012). "Fyll i och skriv på!” Analys av skrivuppgifter i läromedel i svenska för årskurs 4, I Skjelbred, D. \& Veum. A. (red.) Literacy $i$ Laeringskontekster, Oslo: Cappelen Damm Akademisk.

Wirdenäs, K., \& Holmberg, P. (2010). Skrivpedagogik i praktiken: Textkedjor, textsamtal och texttypologier i tre svensklärares klassrum. Språk $\mathcal{E}$ stil, NF 20.

\section{Läromedel}

Andersson, Å. (2013). Skrivnivå 3. Stockholm: Liber.

Bergman, C. \& Jansson, Å. (2011). Grönt ljus Skriva åk 3 Paketerbj 10 ex. Malmö: Gleerups Utbildning AB. Felth Sjölund, I. \& Hed Andersson, P. (2012). Diamantjakten. Arbetsbok. 1. uppl. Stockholm: Natur \& kultur. Hulten, R. (2009a). Forma språket. Skriva. A. 1. uppl. Malmö: Gleerups.

Hultén, R. (2009b). FORMA Språket Paket Basbok Tvåan 20 ex+lärarwebb Individlic. Malmö: Gleerups.

Hultén, R. (2010). Forma språket. Skriva. B. 1. uppl. Malmö: Gleerups.

Hultén, R. (2011a). FORMA Språket Basbok Ettan. Malmö: Gleerups Utbildning AB.

Hultén, R. (2011b). FORMA Språket Paket Basbok Trean. Malmö: Gleerups.

Hultén, R. (2013). Prima svenska. 1. 1. uppl. Malmö: Gleerups utbildning.

Hultén, R. (2015). Prima svenska. 2, [Basbok]. 1. uppl. Malmö: Gleerup.

Hydén, G. (2010). Skriva svenska. Start. Sollentuna: Adastra läromedel.

Hydén, G. \& Martin, R. (2009). Skriva svenska. A. Sollentuna: Adastra läromedel.

Hägg, Å. \& Perlkvist, K. (2014a). Boken om svenska, För 1:an. 1. uppl. Stockholm: Liber.

Hägg, Å. \& Perlkvist, K. (2014b). Boken om svenska, För 2:an. 1. uppl. Stockholm: Liber.

Hägg, Å. \& Perlkvist, K. (2014c). Boken om svenska, För 3:an. 1. uppl. Stockholm: Liber.

Morrison, C. (2004). Bumerang skrivskola. Malmö: Gleerups.

Mårtensson, A. \& Billström, M. (2009). Språkskrinet: vi lär ordkunskap, språklära, skrivning. [troll] 2. tr. Nacka: Majema.

Mårtensson, A. \& Billström, M. (2010). Språkskrinet: vi lär ordkunskap, språklära, skrivning : [clown]. 3. tr. Nacka: Majema.

Sahlin, P. (2008). Skrivmix. Start! : [läs och skriv i genrer]. 1. utg. Stockholm: Natur \& kultur. Kreativitetsdiskursen Kreativitetsdiskursen. 